\title{
The demand of urban residents for the biodiversity conservation in $U$ Minh Thuong National Park, Vietnam
}

\author{
Huynh Viet Khai ${ }^{1,2}$ and Mitsuyasu Yabe ${ }^{2^{*}}$
}

\author{
* Correspondence: \\ yabe@agr.kyushu-u.ac.jp \\ ${ }^{2}$ Laboratory of Environmental \\ Economics, Department of \\ Agricultural and Resource \\ Economics, Faculty of Agriculture, \\ Kyushu University, Hakozaki 6-10-1, \\ Higashi-ku, Fukuoka city 812-8581, \\ Japan \\ Full list of author information is \\ available at the end of the article
}

\begin{abstract}
The total economic value of biodiversity provides policy-makers reliable information to estimate welfare losses caused by biodiversity reductions and perform cost-benefit analysis of biodiversity conservation projects. Searching literature reviews on economic-valuation techniques, the contingent valuation (CV) method has been popularly applied to estimate the economic value of biodiversity. This approach is based on a hypothetical scenario in which respondents are requested through questionnaires to reveal their maximum willingness to pay (WTP) for biodiversity conservation. The article used CV to study the Mekong Delta urban households' preferences and their willingness to pay for the program of biodiversity conservation in $U$ Minh Thuong National Park, one of the largest peat swamp forests in Vietnam. Logistic regression was used to predict the probability of respondents willing to pay for the conservation program. The mean WTP was calculated approximately VND16,510 (\$0.78) per household per month for all respondents and about VND31,520 (\$1.49) after excluding the protest zero and scenario rejecting respondents. Aggregately, Mekong Delta urban residents agreed to contribute about $\$ 10.97$ million annually for the project of biodiversity conservation.
\end{abstract}

Keywords: Contingent valuation; Genetic resources; Wetland conservation; WTP

\section{Background}

Natural wetlands play an important role in terms of controlling water flow, preventing from the damage of flood and storm, supporting fisheries, absorbing waste, especially maintaining biodiversity, etc. In addition, wetland regions are places for water transport and recreation while the diverse resources in wetlands could be directly exploited for agriculture, fishing, water supply, wood and wildlife products. The aggregate economic benefit of a wetland's ecological functions, resources and services could surpass the economic value received from the wetland conversion for alternative uses (Wattage 2002).

There are a number of previous studies using the contingent valuation $(\mathrm{CV})$ method to estimate the total benefit of wetlands. Hanemann et al. (1991) applied the dichotomous choice CV method to estimate willingness to pay (WTP) for wetlands maintenance program in San Joaquin Valley. The study showed that the single-bounded response estimated the mean WTP of \$250 and \$151 from the estimation of double-bounded question. Beran (1995) used CV questionnaires to estimate the passive use values

\section{Springer}

(C) 2014 Khai and Yabe; licensee Springer. This is an Open Access article distributed under the terms of the Creative Commons Attribution License (http://creativecommons.org/licenses/by/2.0), which permits unrestricted use, distribution, and reproduction in any medium, provided the original work is properly credited. 
associated with preservation of freshwater wetlands in South Carolina. The study revealed that mean WTP ranged from a one-time contribution of $\$ 6.03$ to $\$ 45.4$ according to the estimation technique and the type of wetland valued, and a total value of WTP for South Carolina residents was $\$ 3.7$ million. The other study by Chen and Jim (2010) analyzed Guangzhou residents' motivations and WTP for an urban biodiversity conservation program in the National Baiyun Mountain Scenic area. The research estimated the median WTP of $\$ 19.5$ per household per year and the total value of about $\$ 38.2$ million annually to contribute the urban conservation project.

There is great biodiversity in the wetlands of the Mekong Delta, the largest wetlands in Vietnam, assisting a large number of herons, egrets, stocks, ibises and some rare species such as sarus cranes, black necked storks, lesser adjutants and great adjutants. Specially, the mature semi-natural Melaleuca forest and seasonally inundated grasslands of the Mekong Delta wetlands are the living environments of about 14 globally threatened bird species. Therefore, preserving these wetlands is important or beneficial not only for Vietnam but also for the world. Moreover, there are also a lot of unknown flora and fauna, microorganisms, and genetic resources that are expected to contribute to, for example, the future development of new medicines or coenzymes, which are necessary for biochemical reaction.

However, there are so many issues related to environmental pollution and an increase in wetland destruction due to an overheated economic development. Recently, the Mekong Delta wetlands are dealing with the serious biodiversity loss and degradation. For example, the numbers of endangered species (sarus cranes) in Tram Chim National Park - one of the largest national wetland parks - have rapidly decreased from 1,057 in 1987 to 93 in 2005 (Do and Bennett 2007; Khai and Yabe 2014). The degradation of wetland biodiversity is due to an increase in shrimp farming, the conversion of wetlands to agriculture and construction land, war destruction and excessive fuel wood collection. The development of dykes in the Mekong Delta has altered hydrologic conditions and also hence wetland health (Do and Bennett 2007). To prevent from the biodiversity loss and degradation, the local authorities have proposed plans to use public funding to improve the protection of biodiversity. However, up to now there is little information on the values of biodiversity as well as studies on nature and biodiversity conservation in the Vietnam's literature. Thuy (2007) applied the CV method with five bid-level questionnaires to conduct the study on willingness to pay for the conservation of Vietnamese Rhinoceros and estimate the mean WTP of \$2.5 per household. Environmental choice modeling was applied by Do and Bennett (2007) to identify the biodiversity benefits of Tram Chim National Park. The study estimated total benefits of wetland conservation program were about $\$ 3.9$ million.

Because of the limitation of information and studies related to the benefit of biodiversity conservation, policymakers cannot answer the question of whether the change in current management practices would generate net social benefits. It is relatively easy to calculate costs of biodiversity conservation program, but hard to estimate benefits. The benefits or design of biodiversity policy could be estimated by studying public preferences on conservation program. However, this is complicated because of the generally low level of awareness and understanding of what biodiversity means on the part of the general public (Christie et al. 2006). Moreover, although there are a lot of conservation activities especially in biosphere reserves of the Mekong Delta recognized by UNESCO, 
these are not strong or powerful enough to enlarge or improve the quantity and quality of biosphere reserves because of government budget constraint or the low level of support from local residents and authorities. The studies are needed to be done to answer the question of whether is worthy investing more financial resources in conserving biodiversity in these biosphere reserves. In this study, we try to estimate total economic values of proposed biodiversity conservation program in U Minh Thuong National Park using the approach of CV method. The study might partly seek to answer the above questions, and also provide policy makers and concerned people more information about residents' attitudes toward environment and natural resources as well as the benefits of biodiversity conservation.

The article is outlined as follows. The next part presents the empirical model, research area and data collection. The following part discusses about the results of willingness to pay for biodiversity conservation, including the discussions of refusals and zero responses, and the estimation of willingness to pay. The final part withdraws some conclusions of the study.

\section{Empirical method}

This study used CV method to identify the total value of wetland conservation. The CV method was first used at the beginning of the 1960s to estimate the benefits of outdoor recreation in Maine backwoods by Robert (1963). After that, Ridker (1971) applied the CV method for air pollution problems. From the 1970s up to now, this CV approach has been applied by many economists to measure the benefits of a wide variety of goods such as recreation, hunting, water quality, decreased mortality risk from a nuclear power plant accident and toxic waste dumps, etc. (Wattage, 2002).

The basic theory of the dichotomous CV approach was proposed by Hanemann (1984). The idea favored by current CV practice is to ask each respondent a closed from question, namely whether they would accept to pay a given amount to obtain a given change in their status quo. Hence the answers obtained are the type of 'yes' or 'no', necessitating a theory of how to translate these discrete responses into meaningful WTP estimates (Khai and Yabe 2011). Suppose that a respondent is asked to consider the change from the status quo $Q^{0}$ to $Q^{1}$, where $Q^{1}$ refers to the quality of environment and presumably the latter choice is preferable to the former. Denote the indirect utility of respondents as $V(P, Q, I, Z)$, where $P$ is a vector of prices, $I$ is the respondent's income and $Z$ is a vector of respondent characteristics. Then if the respondent is asked whether he would be willing to pay an amount $M$ to obtain $Q^{1}$, his answer would be 'yes' if the following condition holds (where $\operatorname{Pr}$ denotes the probability):

$$
\begin{aligned}
\operatorname{Pr}(\text { Yes }) & =\operatorname{Pr}\left\{V\left(P, Q^{1}, I-M, Z\right)+{ }_{1} \geq V\left(P, Q^{0}, I-0, Z\right)+_{0}\right\} \\
& =\operatorname{Pr}\left\{V\left(P, Q^{1}, I-M, Z\right)-V\left(P, Q^{0}, I-0, Z\right)++_{1}-0 \geq 0\right\}
\end{aligned}
$$

where $\varepsilon_{0}$ and $\varepsilon_{1}$ are unobservable components of the utility and identically and independently distributed (i.i.d) random variable with zero mean. If we define $\Delta V=V\left(P, Q^{1}\right.$, $I-M, Z)-V\left(P, Q^{0}, I-0, Z\right)$ and $\gamma=\varepsilon_{1}-\varepsilon_{0}$, and then write:

$$
\operatorname{Pr}(Y e s)=\operatorname{Pr}(\gamma \geq-\Delta V)=1-F_{\gamma}(-\Delta V)=F_{\gamma}(\Delta V)
$$

where $F_{\gamma}(\Delta V)$ represents the cumulative density function (cdf) of the respondent's true maximum WTP. 
The dichotomous CV technique estimates the mean and median WTPs based on the coefficients related the WTP responses against a constant and the bid (BID). Additional coefficients $(X)$ of other variables like responses to attitude questions or the respondents' demographic information may also be factored into the model. The probit and logit model are commonly applied to analyze the dichotomous choice format of contingent valuation method. In this study, we used the logistic function, which is relatively easier to compute than the approach of probit function. The following form of logistic function could estimate these coefficients:

$$
\operatorname{Pr}(\text { Yes })=F_{\gamma}(\Delta V)=\frac{1}{1+\exp (-\Delta V)}=\frac{1}{1+\exp -\left(\alpha+\beta_{1} B I D+\beta_{2} X\right)}
$$

where $\alpha$ and $\beta$ are coefficients to be estimated and BID is the amount of given money the respondents were asked to pay.

This logistic function was estimated using maximum likelihood. Let $R_{\mathrm{k}}$ be an indicator variable for observation $k$, with

$$
\begin{aligned}
& \operatorname{Pr}(\text { Yes })=\operatorname{Pr}\left(R_{k}=1\right)=\operatorname{Pr}\left(\gamma_{k} \leq \Delta V_{k}\right)=F_{\gamma}\left(\Delta V_{k}\right) \\
& \operatorname{Pr}(N o)=\operatorname{Pr}\left(R_{k}=0\right)=\operatorname{Pr}\left(\gamma_{k} \leq \Delta V_{k}\right)=1-F_{\gamma}\left(\Delta V_{k}\right)
\end{aligned}
$$

So the log-likelihood function is formed as:

$$
\log L=\sum_{k=1}^{N}\left\{R_{k} F_{\gamma}\left(\Delta V_{k}\right)+\left(1-R_{k}\right) \ln \left(1-F_{\gamma}\left(\Delta V_{k}\right)\right)\right\}
$$

In this case, the mean and median WTP are equal to each other and calculated by the following estimator:

$$
\text { Mean } / \text { Median WTP }=-\frac{\left(\hat{a}+\hat{\beta_{2}} \bar{X}\right)}{\beta_{1}^{\wedge}}
$$

\section{Research area and data collection}

U Minh Thuong National Park is one of two largest areas of peat swamp forest in Vietnam. Biodiversity conservation in this region has been assigned a national priority since it can buffer the negative effects of the Mekong River floods, recharge aquifers and provide a unique environment for many wetland species. With a total area of 8.038 ha and a buffer zone of 13.069 ha, the national park is a home of many diversified plants and animals including 243 plant, 32 mammal, 151 bird, 34 reptile, 7 amphibian, 34 fish and 181 insect species. Forty of these are listed as endangered species in the Vietnam Red Book (Dang 2009).

Although the government has declared the protected zone, U Minh Thuong National Park is still under serious threats to biodiversity such as an increase in human encroachment on and disturbance of wildlife habitats by converting the forest land into agriculture and construction land, environmental pollution caused by subsistence 
wastes, industrial wastes, use of insecticides, herbicides and toxic rat baits, illegal wildlife hunting and trade, etc.

Primary data were collected by randomly interviewing local citizens face-to-face in the urban area of Can Tho city, representing the largest city in the Mekong Delta and the urban region of Kien Giang province where U Minh Thuong National Park is located. The time of survey took about 3 mouths from January to March 2013 and was divided into two main periods. The first one was the pilot-survey, in the first week of January 2013. The pilot surveying and pretesting are essential elements in any contingent valuation study (Bateman et al. 1995). The aims of this interview are to refine the questionnaire, format bid starting point more clearly and concisely, and also help interviewers get used to and understand the content of questionnaire. After the interviewers are trained, there are about 50 households interviewed in this period. The revised questionnaire is used in the second period. The sample was composed of 366 respondents, 215 in Can Tho and 151 in Kien Giang. To make a good CV questionnaire without cheap talk bias, the content of questionnaire is formed based on the suggestion of Carson (1991), and Cummings and Taylor (1999). We first examine how the respondents concern environmental problems in the country and recognize respondents' attitude toward biodiversity conservation project. Secondly, the plan of proposed project is introduced with the payment vehicle and provision rule. Finally, socioeconomic information of respondents are collected.

The single-bound dichotomous choice contingent valuation questions were used in the study. Before the CV question was asked, the current conditions, biodiversity as well as the benefits of U Minh Thuong National Park were introduced. Then, we identified some threats of biodiversity loss such as encroachment, disturbance of vegetation, environmental pollution, wildlife hunting, and trade occurring in this area. A hypothetical conservation program was proposed to prevent from biodiversity loss in the national park. Biodiversity will continue to degrade more seriously without this conservation project. The study proposed funding a biodiversity conservation project to increase the number of plants and animals in U Minh Thuong National Park or at least keep them from declining every year. The conservation fund could then request international organizations to provide the same amount of money or more compared with the contributions of residents. The raised money would be only used for conservation activities in U Minh Thuong National Park (See the section of CV question for more details in the Appendix). The payment vehicle was used as voluntary continuous donation, contributed through a monthly water bill for three years, which could catch the present value of preferences for biodiversity conservation and also prevent potential protests due to compulsory payment like taxes (Rolfe et al., 2000). Each household was interviewed whether he/she would be willing to contribute the biodiversity conservation fund a certain amount of money every month as surcharge on his/her household water bills for the next three years. The admissible answers were 'yes' or 'no'. Five different bid values of VND10,000, VND35,000, VND60,000, VND85,000 and VND110,000 were chosen for the study. These values are equivalent to values in US dollars ${ }^{\mathrm{a}}$ of $\$ 0.47, \$ 1.66, \$ 2.84, \$ 4.21$ and $\$ 5.20$, respectively. Each household was randomly interviewed whether he/she would be willing to contribute one of these bid values and answered whether he/she accepted only one bid value. For example, the respondent was asked 'Would you be willing to pay VND10,000 every month for biodiversity conservation program in U Minh Thuong?' If the answer was 'yes', the list of 'yes' reasons 
was then presented. If the response was 'no', the list of 'no' reasons was then introduced and an open-end question was also asked whether a respondent would like to contribute another lower amount of money to identify the categories of protest zero, valid zero and WTP less bids.

\section{Results and discussion}

\section{Refusals and zero responses}

Table 1 shows the probability of answering 'no' increases as the amount of money the respondents are asked to pay increases. About $68.6 \%$ of respondents disagree to pay the given discrete choice amount, and $39.3 \%$ of those are not willing to pay any positive amount. Possible explanations for the high number of refusals and zero responses may be that respondents are not familiar with this kind of survey, the study might be too hypothetical or the scenarios could be too unspecific and simplistic. Interviewees who do not agree to pay the amount of money given in the questionnaire were asked why they had responded 'no'. Table 2 gives the overall frequencies of answers from a given list of reasons.

Table 2 reveals reasons for refusing to pay the given discrete amount of money. About 51 percent of respondents cannot afford to pay or have not space income to contribute towards the fund of biodiversity conservation (reason 1). Such high percentage of unwilling-to-pay reason due to the income constraint is consistent with other survey study in developing countries. The study on saving the Philippine Eagle by Harder et al. (2006) showed a 62 percent while the study on Vietnamese Rhinoceros conservation by Thuy (2007) revealed about 41 percent of respondents refusing to contribute the conservation program due to income constraint. The second highest-cited reason accounted for 16.3 percent of respondents who think that the biodiversity conservation program should be the government' responsibility since it has money from tax revenues while about 12 percent of unwilling-to-pay respondents with the reason of distrusting the institutions that will handle the money for this conservation work.

This study follows the other previous CV studies to discriminate between valid and 'protest' zero bids. The respondents who are not willing to pay any positive bids with the reason 4 (I do not believe paying will solve the problem), 6 (I do not trust the institutions that will handle the money for this conservation work) and 7 (It should be the

Table 1 Respondents refusing the discrete choice amount or refusing to pay any amount for biodiversity conservation

\begin{tabular}{|c|c|c|c|c|c|}
\hline \multirow[t]{2}{*}{ Bid value (VND) } & \multirow[t]{2}{*}{ Observations } & \multicolumn{2}{|c|}{$\begin{array}{l}\text { Refusals to the discrete } \\
\text { choice question }\end{array}$} & \multicolumn{2}{|c|}{$\begin{array}{l}\text { Refusals to make any positive } \\
\text { payment }\end{array}$} \\
\hline & & Number & Percent (\%) & Number & Percent (\%) \\
\hline 10,000 & 76 & 33 & 43.4 & 28 & 36.8 \\
\hline 35,000 & 77 & 48 & 62.3 & 28 & 36.4 \\
\hline 60,000 & 74 & 55 & 74.3 & 29 & 39.2 \\
\hline 85,000 & 72 & 59 & 81.9 & 32 & 44.4 \\
\hline 110,000 & 67 & 56 & 83.6 & 27 & 40.3 \\
\hline Total & 366 & 251 & 68.6 & 144 & 39.3 \\
\hline
\end{tabular}

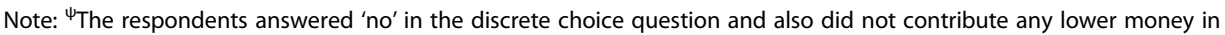
the open-end question.

Source: Own estimates; data appendix available from authors. 
Table 2 Respondents giving reasons for refusing to pay the given discrete choice amount

\begin{tabular}{|c|c|c|}
\hline Reason & Number & Percent (\%) \\
\hline 1 = I cannot afford to pay/l have no spare income. & 128 & 51.0 \\
\hline $2=\mid$ feel the environmental improvement of $U$ Minh Thuong is unimportant. & 3 & 1.2 \\
\hline $3=$ Being far from the place, I feel paying anything is irrelevant to me. & 13 & 5.2 \\
\hline $4=\mid$ do not believe paying will solve the problem. & 18 & 7.2 \\
\hline $5=\mid$ feel this improvement will take place without my contribution. & 7 & 2.8 \\
\hline $\begin{array}{l}6=\text { I do not trust the institutions that will handle the money for this } \\
\text { conservation work. }\end{array}$ & 30 & 12.0 \\
\hline $\begin{array}{l}7=\text { It should be the government's responsibility since it has money from tax } \\
\text { revenues. }\end{array}$ & 41 & 16.3 \\
\hline $8=$ Other reasons. & 11 & 4.4 \\
\hline
\end{tabular}

Source: Own estimates; data appendix available from authors.

government's responsibility since it has money from tax revenues) are listed into the category of 'protest vote' or none-zero value. The percentages of respondents in the protest bid, valid no and positive bid categories are performed in Table 3.

Table 3 shows about 60.7 percent of respondents willing to pay some positive amount for conservation program while about 29.2 percent of respondents agree to pay less than the bid values (The respondents who disagreed to pay the amount of money given in the questionnaire but accepted to contribute a smaller amount of money) and around 24.6 percent of respondents are categorized as valid zero bids (the respondents were not willing to pay any amount of money for conservation program with any other reasons excepting the reason 4, 6 and 7). The study also shows that the proportion of protest bids averages 14.8 percent of all responses. Such figure is somewhat consistent with other results in the literature. Kirkland (1988) has 18 percent of protest responses in his study, about 24 percent are determined by Sappideen (1992) and 28 - 31 percent of protest bids in the study by Jakobsson and Dragun (1996). According to Moser and Dunning (1986), the high level of protest bids reveals that some questions could be misunderstood; the respondents have troubles to understand the study scenario or are not convinced that the proposed project becomes real.

\section{Estimation of willingness to pay}

Table 4 shows the socio-demographic description of the respondents. The age of surveyed respondents ranges from 20 to 87 years with the average age of 50 years and about 62 percent of respondents are female. The high percentage of female respondents

Table 3 The category of protest bid, valid no and positive bid respondents

\begin{tabular}{lrr}
\hline & Number & Percent (\%) \\
\hline Protest zero bids (1) & 54 & 14.8 \\
Valid zero bids (2) & 90 & 24.6 \\
WTP less bids (3) & 107 & 29.2 \\
Willing to pay discrete choice amount (4) & 115 & 31.4 \\
Willing to pay some positive amount (5) & 222 & 60.7 \\
\hline
\end{tabular}

Note: $(5)$ = Total observations - Protest zero bids (1) - Valid zero bids (2) Source: Own estimates; data appendix available from authors. 
may be due to the survey mainly done in the daylight of weekdays when it is difficult to interview working male households. Regarding the level of education, around 23 percent of respondents stated a university and higher degree. The average household income is over VND7.5 million per month with the most frequent category of below VND5 million (40\%), followed by VND5 million - 10 million (about 39\%), and over VND10 million (nearly $21 \%$ ). The higher household income level of the sample in comparison with the average household income of Mekong Delta residents (about 5.2 million per month in $2010^{\mathrm{b}}$ ) does not show a problem in terms of a sample selection bias because the difference could be explained by the inclusion of rural households who earn lower income than urban residents in the population average.

In the contingent valuation literature, there are some ways to solve the problem of zero bids. Imber et al. (1991) treat all 'no' responses as real 'no' answers. This may result in wrong policy implications (Carson 1991) or difficultly estimate the willingness to pay function correctly if the number of protest responses is high (Romer 1992). Other strategy is to eliminate all zero bids, but this may cause a sample selection bias, since the remaining bids from no longer originate from a random sample of the basic population (Romer 1992). The most common way is to identify and exclude protest bids from estimates of willingness to pay (Mitchell and Carson 1989). The estimates without protest responses give the higher value of WTP than those with all 'no' responses. In this study, we use the WTP estimate without protest bids as the mean WTP and the WTP calculation for all 'no' responses as the low bound of willingness to pay.

The one of the key questions in a contingent valuation survey is whether WTP is affected by important variables suggested by economic theory, for example income, education, age, etc. or whether the coefficients of these variables have signs that are consistent with expectations. These relationships analyzed by logistic function are performed in Table 5 .

Table 5 shows the results of a logistic analysis of the dichotomous choice responses to the contingent valuation questions. The model 1 is the estimates for all respondents and the model 2 shows the results after excluding protest bids. The predictive powers of models are relatively high, with nearly 76 percent in model 1 , and over 74 percent in model 2. The correlation matrix across explanatory variables supports the absence of

Table 4 Descriptive statistics of variables in the logistic function

\begin{tabular}{|c|c|c|c|c|c|}
\hline Variables & Description & Mean & Std.Dev. & Min. & Max. \\
\hline$\overline{W T P}$ & Willingness to pay for conservation program $(1=$ yes, $0=\mathrm{No})$ & 0.314 & 0.465 & 0 & 1 \\
\hline Bid & Bid value (thousand VND) & 58.421 & 35.107 & 10 & 110 \\
\hline Age & Age of respondents (years) & 49.713 & 14.281 & 20 & 87 \\
\hline Gender & Gender of respondents ( $1=$ Male, $0=$ Female) & 0.385 & 0.487 & 0 & 1 \\
\hline Graduate & $\begin{array}{l}\text { Educational level of respondents ( } 1=\text { Graduate or higher, } \\
0=\text { otherwise) }\end{array}$ & 0.232 & 0.423 & 0 & \\
\hline Status & Civil status of respondents ( $1=$ married, $0=$ otherwise $)$ & 0.872 & 0.335 & 0 & 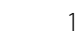 \\
\hline Income & Monthly household income of respondents (thousand VND) & 7,547 & 4,073 & 4,500 & 19,500 \\
\hline Location & Location of respondents ( $1=$ Can Tho, $0=$ Kien Giang) & 0.587 & 0.493 & 0 & \\
\hline Donation & Whether respondents have made any donations $(1=$ yes, $0=$ no $)$ & 0.702 & 0.458 & 0 & 1 \\
\hline
\end{tabular}

Source: Own estimates; data appendix available from authors. 
Table 5 Logistic regression estimate of willingness to pay for conservation project

\begin{tabular}{|c|c|c|c|c|}
\hline & Model 1 (All & dents included) & Model $2(\mathrm{Pr}$ & bids excluded) \\
\hline & Coefficient & Standard error & Coefficient & Standard error \\
\hline Bid & $-0.0230^{* * *}$ & 0.004 & $-0.0263^{* * *}$ & 0.004 \\
\hline Age & $-0.1133^{* *}$ & 0.055 & $-0.0997^{*}$ & 0.058 \\
\hline Age*Age & $0.0010^{*}$ & 0.001 & $0.0010^{*}$ & 0.001 \\
\hline Gender & 0.3580 & 0.262 & $0.7380^{* *}$ & 0.292 \\
\hline Graduate & -0.1298 & 0.327 & -0.1577 & 0.359 \\
\hline Status & $0.7818^{*}$ & 0.459 & 0.3833 & 0.473 \\
\hline Log(Income) & $1.0777^{* * *}$ & 0.303 & $1.3601^{* * *}$ & 0.344 \\
\hline Location & 0.1688 & 0.266 & 0.2740 & 0.288 \\
\hline Donation & $0.7656^{* * *}$ & 0.296 & $0.8066^{* *}$ & 0.317 \\
\hline Constant & $-7.6845^{* * *}$ & 2.809 & $-10.0204^{* * *}$ & 3.142 \\
\hline Pseudo $\mathrm{R}^{2}$ & 0.156 & & 0.198 & \\
\hline Log likelihood & -192.230 & & -164.808 & \\
\hline Correct prediction (\%) & 75.956 & & 74.359 & \\
\hline Observations (N) & 366 & & 312 & \\
\hline
\end{tabular}

Notes: ${ }^{* *}, * * * *$ indicate statistical significance at the $0.01,0.05$ and 0.1 level respectively.

Source: Own estimates; data appendix available from authors.

multicollinearity because there are no correlation indices that are higher than 70 percent (Khai and Yabe 2013). The coefficients of the bid value in the two models are statistically significant and negative as expected, revealing that an increase in bid amount could reduce the 'yes' response and the existence of the WTP for conservation program. Consistently with other studies by Subade (2005) and Jianjun (2007), the coefficients of Age variable in the two models are statistically significant and have negative signs, implying the older respondents have more tendency to say 'no' to the WTP question. However, the residents in the sample from the age ${ }^{\mathrm{c}}$ of 57 are more likely to recognize the necessary of biodiversity conservation and agree to support the project since the parameters of Age*Age variable are significantly positive at 10 percent level. The coefficients of household Income are significant at the level of 1 percent. The positive sign of Income suggests higher income could increase the probability of 'yes' answer to the contingent valuation question. Regarding the motivations for conservation, the variable of Donation is defined as whether a respondent have ever donated for any charitable or environmental funds. The coefficients of Donation variable in two models are significantly positive, revealing respondents who have made any donation in the past are more willing to pay for the biodiversity conservation project. From the findings in Table 5 and applying the estimator (6), the median and mean WTP for the proposed biodiversity conservation project are calculated by utilizing the directly estimated values of the coefficients. The results of mean and median estimates of willingness to pay are presented in the Table 6.

Table 6 performs the mean WTP for all respondents is estimated to be VND16,510 with the 95\% confident interval between VND-4,670 and VND29,340 while the mean WTP after excluding protest vote respondents increases up to VND31,520 with the 95\% confident interval between VND17,860 and VND43,670. The two mean WTPs are significantly positive at the level of 10 percent for all respondents and 1 percent for the sample with protest bids excluded. 
Table 6 Willingness to pay for biodiversity conservation program unit: thousand VND

\begin{tabular}{lcccc}
\hline & Mean/Median of WTP & \multicolumn{3}{c}{ 95\% Confidence Interval } \\
\cline { 3 - 5 } & & Lower bound & Upper bound & ASL \\
\hline All respondents included & 16.51 & -4.64 & 29.34 & 0.053 \\
Protest bids excluded & 31.52 & 17.86 & 43.67 & 0.0008 \\
\hline
\end{tabular}

Note: ASL: Achieved Significance Level for testing $\mathrm{H}_{0}$ : WTP $<=0$ vs. $\mathrm{H}_{1}$ : WTP $>0$.

Confidence intervals are estimated by the Krinsky and Robb (1986) method.

Source: Own estimates; data appendix available from authors.

\section{Conclusions}

This study tried to extend the understanding of Vietnamese households' preferences for biodiversity conservation to the context of their WTP. The mean WTP for the proposed conservation project was calculated to be approximately VND16,510 per household per month, which was about 0.32 percent of the average household income at VND5.2 million per month in the Mekong Delta region in 2010. Moreover, the study also estimated the mean WTP of VND31,520 per household per month after excluding the protest zero and scenario rejecting respondents. An aggregate welfare measure can be derived by multiplying the mean WTP by the total urban households in the Mekong Delta. According to the general statistics office (GSO 2013), there were 4,329,100 urban people in the Mekong Delta in 2012, which were equivalent to 1,170,027 urban households with the average of 3.7 persons per urban family (Binh 2011). The calculation discovered that Mekong Delta urban residents were willing to pay about VND19.32 billion (VND16,510* 1,170,027 urban households) every month for biodiversity conservation. Therefore, the total value of annual urban resident's contribution is approximately VND231.81 billion ( $\$ 10.97$ million) which is relatively big enough for the government, policy makers and concerned people to pay more attention or give more financial invests in conserving and improving wildlife habitats and biodiversity in U Minh Thuong National Park. This total value could be the useful and trustworthy information for decision makers to allocate funds for the biodiversity conservation project while the results of this contingent valuation study could also be valuable for environmental evaluation or suggest applying this approach to the cost-benefit analysis of this project as well as other or future projects in Vietnam. In addition, the public evaluation of biodiversity conservation could help society more awareness on the important role of biodiversity, have an impact on rational behaviors or wide support of residents to improve the quantity or quality of biodiversity which benefits the present and future generation (Chen and Jim 2010).

\section{Endnotes}

${ }^{\mathrm{a}} 1 \mathrm{USD}=21,140 \mathrm{VND}$ at the date of 05/12/2013.

${ }^{\mathrm{b}}$ The average household income of Mekong Delta residents are calculated by multiplying per capital income at 1.25 million (GSO 2010) with the average member of 4.16 per family (Binh 2011) in the Mekong Delta region.

${ }^{\mathrm{c}}$ At the minimum of $\operatorname{Pr}(\mathrm{Yes})$ function, $A g e_{\min }=-(-0.1133) /(2 * 0.001)=56.65$.

\section{Appendix: the format of CV question}

\section{Section 3: A conservation plan for the protection of U Minh Thuong National Park}

We will now provide you some information about U Minh Thuong in Kien Giang: 
U Minh Thuong National Park is one of two large areas of peat swamp forest in Vietnam. Biodiversity conservation in this region has been assigned a national priority since it could buffer the negative effects of the Mekong River floods, recharge aquifers and provide a unique environment for many wetland species. With a total area of 8.038 ha and a buffer zone of 13.069 ha, the Park is a home of many diversified plants and animals including 243 plant, 32 mammal, 151 bird, 34 reptile, 7 amphibian, 34 fish and 181 insect species. Forty of these are listed as endangered species in the Vietnam Red Book.

\section{Threats to biodervisty in U Minh Thuong National Park}

Although the government has declared the protected zone, U Minh Thuong is still under serious threats to biodiversity:

- Encroachment and disturbance of habitats: due to high density of local peoples, habitat area often undergoing encroachment for agriculture, aquaculture and other purposes. This activity is especially in the areas outside protected areas. Illegal encroachment causes lots of disturbance for habitat security.

- Environmental pollution caused by subsistence wastes, industrial wastes, use of insecticides, herbicides and toxic rat baits.

- Wildlife hunting and trade occurs commonly in the area. Wild animals in general and mammals in particular are hunted for household use and also for sale in urban centers.

\section{A conservation plan for biodiversity in U Minh Thuong National Park}

The goal of the program is to increase the number of plants and animals in U Minh Thuong or at least keep them from declining every year. To accomplish this goal, it should be carried out the following activities:

- Rationally planning ponds, shrimp ponds and rice farming land around the buffer zone to prevent water pollution and scarcity of food.

- Planting more trees suitable for nesting and reproducing, improving ponds, swamps and grassland within and outside the buffer zone to create a food source and the better living environment for wild animals. There is also promoting tree planting in rural areas, industrial zones and urban areas to create the good habitat conditions for the biodiversity conservation.

- Enhancing the coverage of forest to protect the soil from erosion, landslides and runoff.

- Conducting education and training activities to improve the awareness of the local people to conserve biodiversity and the professional skills of the management group staff.

While the program contains many good ideas, implementing it would require money. So far, the program has not received any funding or carried out any activities. A number of international organizations do provide financial support to protect this biodiversity area. However, they usually require that counterpart funds be made available. In other words, people from region must also contribute money to protection effort. 
Therefore, the practical implementation of this program would require much more concerted efforts from all households.

\section{Conservation fund}

Suppose a conservation fund for biodiversity in U Minh Thuong would be set up, all citizens could contribute to the fund. The fund could then request international organizations to provide the same amount of money or more, according to the money raised locally. The money raised by the fund would be ONLY used for the conservation activities mentioned earlier to conserve biodiversity in U Minh Thuong.

The purpose of our survey is to find out if your household would be willing to contribute < bid level $>$ every month as a surcharge on your household water bills for the next three years. The payment is a fixed amount and it doesn't change with the volume of water used. This money would go to the conservation fund for biodiversity in $U$ Minh Thuong.

[The recent study shows that people generally accept to contribute value more than the ability of actual contribution. This survey tries to get information on the ability of your actual contribution. So, require you to think carefully with your decision].

11) Would you be willing to pay < bid level > every month for biodiversity conservation in U Minh Thuong?

(1) Yes (2) No

\section{Competing interests}

The authors declare that they have no competing interests.

\section{Authors' contribution}

HVK designed the study questionnaire, collected and analyzed the data, and drafted the manuscript. MY supervised the research and made critical revisions to the manuscript. All authors read and approved the final manuscript.

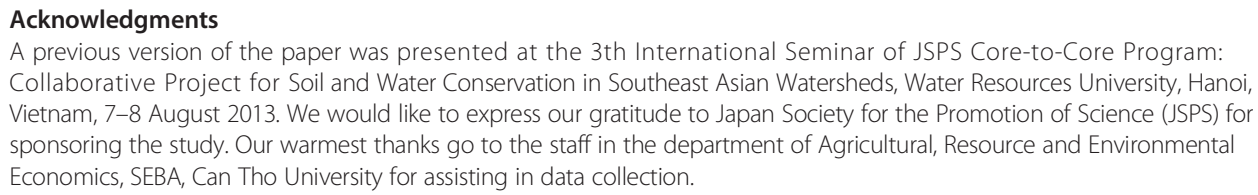

\section{Author details}

${ }^{1}$ Department of Agricultural, Resource and Environmental Economics, School of Economics and Business Administration, Can Tho University, Can Tho City, Vietnam. '2Laboratory of Environmental Economics, Department of Agricultural and Resource Economics, Faculty of Agriculture, Kyushu University, Hakozaki 6-10-1, Higashi-ku, Fukuoka city 812-8581, Japan.

Received: 25 October 2013 Accepted: 10 June 2014

Published online: 01 August 2014

\section{References}

Bateman IJ, Langford IH, Turner RK, Willis KG, Garrod GD (1995) Elicitation and Truncation Effects in Contingent Valuation Studies. Ecol Econ 12(2):161-179, doi:10.1016/0921-8009(94)00044-V

Beran LJ (1995) Measuring the Economic Benefits of Provision of Nonmarket Goods: Freshwater Wetlands in South Carolina. Dissertation, Clemson University, Clemson, South Carolina, US

Binh NT (2011) The trend of Vietnamese household size in recent years. In: 2011 International Conference on Humanities, Society and Culture IPEDR Singapore. IACSIT Press, Singapore, pp 47-52

Carson RT (1991) The Resource Assessment Commission's Kakadu Conservation Zone contingent valuation study. Remarks on the Brunton, Stone and Tasman Institude critiques. In: Commission ARA (ed) Commentaries on the Resource Assessment Commission's contingent valuation survey of the Kakadu Conservation Zone. San Diego, March, Canberra, Department of Economics, University of California

Chen W, Jim CY (2010) Resident Motivations and Willingness-to-Pay for Urban Biodiversity Conservation in Guangzhou (China). Environ Manage 45(5):1052-1064, doi:10.1007/s00267-010-9478-2 
Christie M, Hanley N, Warren J, Murphy K, Wright R, Hyde T (2006) Valuing the diversity of biodiversity. Ecol Econ 58 (2):304-317

Cummings RG, Taylor LO (1999) Unbiased value estimates for environmental goods: A cheap talk design for the contingent valuation method. Am Econ Rev 89(3):649-665, doi:10.1257/Aer.89.3.649

Dang NX (2009) Biodiversity survey - Rapid assessment of flora and terrestrial aninimals in the key areas of Kien Giang Biosphere Reserve. Technical Report 09E0809DANG. Conservation and Development of the Biosphere Reserve of Kien Giang Provine Project, Rach Gia city, Kien Giang Province, Vietnam

Do TN, Bennett J (2007) Would wet biodiversity conservation improve social welfare? A case study in Vietnam's Mekong River Delta. In: The Proceedings of the GMSARN International Conference on Sustainable Development: Challenges and Opportunities for GMS, Pattaya, Thailand

GSO (2010) Result of Viet Nam: Household living standards survey 2010. Statistical Publishing House, General Statistics Office, Ha Noi, Vietnam

GSO The average of urban population by location. General Statistics Office. http://www.gso.gov.vn/default.aspx? tabid=387\&idmid=3\&ltemID=12869. Accessed 6/11 2013

Hanemann M, Loomis J, Kanninen B (1991) Statistical Efficiency of Double-Bounded Dichotomous Choice Contingent Valuation. Am J Agr Econ 73(4):1255-1263, doi:10.2307/1242453

Hanemann WM (1984) Welfare Evaluations in Contingent Valuation Experiments with Discrete Responses. Am J Agr Econ 66(3):332-341, doi:10.2307/1240800

Harder DS, Labao R, Santos FI (2006) Saving the Philippine Eagle: How Much Would It Cost and are Filipinos Willing to Pay for It? The Economy and Environment Program for Southeast Asia (EEPSEA), Singapore

Imber D, Stevenson G, Wilks L (1991) A contingent valuation survey of the Kakadu conservation zone. RAC Research Paper No. 3, AGPS, Canberra

Jakobsson KM, Dragun AK (1996) Contigent Valuation and Endangered Species. Edward Elgar Publishing Limited, Cheltenham, UK

Jianjun J (2007) Economic Valuation of Black-faced Spoonbill Conservation in Macao. The Economy and Environment Program for Southeast Asia (EEPSEA), Singapore

Khai HV, Yabe M (2011) An Analysis of Willingness to Pay for Commodity Insurance of Rice Production in Vietnam. Asian Afr J Econ Econometrics 11(2):485-493

Khai HV, Yabe M (2013) Impact of Industrial Water Pollution on Rice Production in Vietnam. In: Quinn NWT (ed) International Perspectives on Water Quality Management and Pollution Control. InTech Publishing, Rijeka, Croatia, pp 61-85

Khai HV, Yabe M (2014) Choice modeling: assessing the non-market environmental values of the biodiversity conservation of swamp forest in Vietnam. Int J Energy Environ Eng 5(1):1-8, doi:10.1007/s40095-014-0077-5

Kirkland WT (1988) Preserving the Whangamarino Wetland - An Application of Contingent Valuation Method. Master thesis, Massey Uiversity, New Zealand

Krinsky I, Robb AL (1986) On Approximating the Statistical Properties of Elasticities. Rev Econ Stat 68(4):715-719, doi:10.2307/1924536

Mitchell RC, Carson RT (1989) Using surveys to value public goods: The contingent valuation method. RFF Press, Washington DC

Moser DA, Dunning CM (1986) A guide for using the contingent value methodology in recreation studies. National Economic Development Procedures Manual - Recreation, vol Vol II. US Army Corps of Engineers, Water Resources Support centre, Institute for Water Resources, Washington DC, US

Ridker RG (1971) Economic Costs of Air Pollution Studies. Praeger Publishers, USA

Robert KD (1963) The Value of Outdoor Recreation: An Economic Study of the Maine Woods. Harvard University, Cambridge, US

Rolfe J, Bennett J, Louviere J (2000) Choice modelling and its potential application to tropical rainforest preservation. Ecol Econ 35(2):289-302, doi:10.1016/S0921-8009(00)00201-9

Romer AU (1992) How to handle strategic and protest bids in contingent valuation studies. An application of the two-step Heckman procedure. Paper presented at the international conference on 'Econometrics of Europe 2000' of the Applied Econometric Association, Brussels

Sappideen B (1992) Valuing the recreational benefits of the Sale wetlands using the contigent valuation method. In: Lockwood MD,T (ed) Valuing natural areas: Applications and problems of the contingent valuation method. Johnstone Center, Charles Sturt University, Albury

Subade RF (2005) Valuing Biodiversity Conservation in a World Heritage Site: Citizens' Non-use Values for Tubbataha Reefs National Marine Park, Philippines. The Economy and Environment Program for Southeast Asia (EEPSEA), Singapore

Thuy DT (2007) Willingness To Pay for Conservation of the Vietnamese Rhino. The Economy and Environment Program for Southeast Asia (EEPSEA), Singapore

Wattage P (2002) Effective Management Biodiversity Conservation in Sri Lankan Coastal Wetlands: CVM1 - Literature Review. University of Portsmouth Cemare, United Kingdom 